\title{
Neochroococcus gongqingensis gen. et sp. nov., a new member of coccoid cyanobacteria from a watercourse, Eastern China
}

\author{
Ruozhen GenG ${ }^{1,2}$, Yilang WAnG ${ }^{1,2}$, Fangfang $\mathrm{CAI}^{1,2}$, Yige ZHANG ${ }^{1,3}$, Ping YANG ${ }^{4}$, \\ Guofei DAI ${ }^{4}$, Renhui $\mathrm{LI}^{1,5}$ \& Gongliang $\mathrm{YU}^{1}{ }^{*}$
}

\author{
${ }^{1}$ Key Laboratory of Algal Biology, Institute of Hydrobiology, Chinese Academy of Sciences, Wuhan 430072, \\ China; *Corresponding author e-mail: yugl@ihb.ac.cn \\ ${ }^{2}$ University of Chinese Academy of Sciences, Beijing 100039, China \\ ${ }^{3}$ College of Life Sciences, Jiangxi Normal University, Nanchang 330022, China \\ ${ }^{4}$ Jiangxi Province Institute of Water Sciences, Nanchang 330029, China \\ ${ }^{5}$ College of Life and Environmental Sciences, Wenzhou University, Wenzhou, Zhejiang 325039, China
}

\begin{abstract}
The taxonomy of coccoid cyanobacteria has been largely revised in recent years. In this study, a novel coccoid cyanobacterial strain was isolated from a watercourse at the Poyang Lake Model Research Base, Jiangxi province, Eastern China. A polyphasic approach combining morphological and molecular testing was used to characterize this strain referred to as CHAB 4018. Regarding colonial form and cellular spatial arrangement, this strain was morphologically similar to strains of the genus Eucapsis. The maximum 16S rRNA gene sequence similarity of this strain to the currently described cyanobacteria genera was $93.40 \%$, exceeding the cutoff for genus delimitation in bacteriology. Furthermore, a phylogenetic tree based on 16S rRNA gene sequences indicated that strain CHAB 4018 formed a unique clade in the family Chroococcaceae and was phylogenetically close to the recently established genus Cryptococcum but distant from the Chroococcus 'sensu stricto' clade and from Eucapsis. Thus, a novel coccoid cyanobacterial genus with a new species is here described as Neochroococcus gongqingensis. A large phylogenetic tree using more strains suggested phylogenetic intermixture of Chroococcus-like and Eucapsis-like cyanobacteria, suggesting the need for further studies on the phylogeny and taxonomy of coccoid cyanobacteria.
\end{abstract}

Key words: Coccoid cyanobacteria, Neochroococcus gongqingensis, Eucapsis, Polyphasic, Taxonomy

\section{INTRODUCTION}

The taxonomic system of cyanobacteria was considerably revised during the past decades after molecular biological methods became common standard, and primary usage of the polyphasic approach of research on cyanobacterial taxonomy led to substantial revisions and establishment of numerous new genera and species to resolve phylogenetically monophyletic categories (KomÁreK et al. 2014; KomáreK 2016). Along with this revision process, nostocacean cyanobacteria have largely encountered a considerable rearrangement of taxonomic units. In contrast, information from polyphasic studies on the coccoid type of cyanobacteria was relatively poor.

The genus Eucapsis Clements et Shantz, which is considered one of the most typical genera of coccoid cyanobacteria, was well characterized by its spherical cells arranged into regular cubic colonies, and its colorless, hyaline mucilage typically containing $8-16$ but sometimes up to 512 cells was also described (CLEMENTS \& Shantz 1909; KomáreK \& Anagnostidis 1998). At present, Algaebase contains 13 species of Eucapsis which are generally accepted as separate taxa, whereas during the $20^{\text {th }}$ century, only two main species (E. alpina Clements et Shantz and E. minor (Skuja) Elenkin) were commonly referred to (KoMÁREK \& ANAGNOSTIDIS 1998). Progress has been made on several coccoid genera but Eucapsis was not among them, only two 16S rRNA gene sequences of approximately $1400 \mathrm{bp}$ are available which do not provide any taxonomic support (Eucapsis minor SAG 14.99 and Eucapsis sp. 019). During phylogenetic analysis examining the variability of Chroococcus morphotypes, KomárKoví et al. (2010) transferred two Chroococcus strains with small cells into a cluster representing Eucapsis. Furthermore, KомÁREK et al. (2016) defined the Eucapsis cluster by morphological and phylogenetic points of view in which six strains including Eucapsis minor SAG 14.99, Eucapsis sp. 019, three Chroococcus strains with small cells, and 
Aphanothece hegewaldii SAG 253.80, and they found phylogenetic evidence of the genus Eucapsis being more closely related to the family Merismopediaceae than to Chroococcaceae. This systematic also supports the latest system of KomÁREK et al. (2014) who proposed that Eucapsis belongs to the family Merismopediaceae. However, as described by KoMÁREK et al. (2016), using polyphasic criteria, the classification of Eucapsis remains unclear. The scarcity of strains belonging to Eucapsis and absence of strains of its type species are the main problems limiting further polyphasic research. Therefore, more strains of Eucapsis and morphologically similar genera are urgently required.

In the current study, a novel coccoid cyanobacterial strain was isolated from a watercourse in the city of Gongqing, Jiangxi province, China, and was found to form cubic colonies with cells dividing regularly in three perpendicular planes, resembling colonies of the genus Eucapsis. 16S rRNA gene sequence homology and phylogenetic analyses indicated that this strain represents a novel genus of the family Chroococcaceae. The new genus Neochroococcus and its type species Neochroococcus gongqingensis are described here.

\section{Materials AND Methods}

Sampling and cultivation. A water sample was collected using a plankton net in June 2018 from a watercourse at the Poyang Lake Model Research Base in the city of Gongqing city, Jiangxi Province, China. Single Eucapsis-like colonies were isolated using the Pasteur pipette washing method under 40 times microscope (Olympus CKX31, Japan), and were then cultured in 24-well plates containing sterilized liquid MA medium (WATANABE \& HiroKi 1997). In two weeks, the content of wells containing blue-green colonies was transferred into screw-capped tubes containing $10 \mathrm{~mL}$ MA medium, thereby isolating a strain exhibiting cubic colonies. The isolated strain was maintained at $25{ }^{\circ} \mathrm{C}$ under a $12: 12 \mathrm{~h}$ light:dark cycle of white fluorescent light with a photon flux density of $35 \mu \mathrm{mol}$. photons. $\mathrm{m}^{-2} \cdot \mathrm{s}^{-1}$. The strain was archived in the culture collection of the Collection of Harmful Algae Biology laboratory (CHAB) of the Institute of Hydrobiology, Wuhan, China, under the strain number CHAB 4018.

Morphological and ultrastructural characterization. Morphological observation of CHAB 4018 at different growth phases was carried out using a Nikon Eclipse 80i microscope (Nikon, Japan). Microphotographs were produced using a DS-Ri1 digital camera (Nikon, Japan) photomicrographic system and were analyzed using NIS-Elements D 3.2 software (Nikon). Morphometric characteristics of unialgal cells were recorded using digital images recorded at 400-fold magnification, and the mean cellular size was measured in more than 100 cells. For transmission electron microscopy (TEM), cells of the strain were fixed using $2.5 \%$ glutaraldehyde in $0.1 \mathrm{M}$ phosphate buffer at a pH 7.2 and $4{ }^{\circ} \mathrm{C}$ for three days. The samples were then washed using $0.1 \mathrm{M}$ phosphate buffer after which they were post-fixed using $1 \%$ osmium tetroxide for $2 \mathrm{~h}$. Subsequently, the samples were washed again using $0.1 \mathrm{M}$ phosphate buffer to remove osmium tetroxide after which they were dehydrated using a sequential ethanol gradient $(30 \%, 50 \%, 70 \%, 90 \%$, and $100 \%$ ) and then embedded in Spurr's resin (SPURR 1969). The embedded specimens were trimmed using an ultra-microtome (Leica Ultracut UCT, Austria) with a razor blade and were then sectioned into $80-\mathrm{nm}$ slices. Uranyl acetate $(2 \%)$ and lead citrate were used to stain the sections. The specimens were examined using an HT7700 (Japan) transmission electron microscope under $80 \mathrm{kV}$ on Hitachi TEM system control (Hitachi, Japan).

DNA extraction and PCR amplification. The strain cultures were collected by filtration using a Millipore filter $(3.0 \mu \mathrm{m}$ aperture, Merck Millipore, Darmstadt, Germany) and were washed three times using sterile phosphorus-free MA medium to avoid contamination with other bacteria. The remaining biomass was then collected in several clean EP tubes. Total genomic DNA was extracted using a modified cetyltrimethylammonium bromide (CTAB) method (NEILAN et al. 1995). The PCR primers PA (EDwARDS et al. 1989) and B23S (GKelis et al. 2005) were used to amplify a $16 \mathrm{~S}$ rRNA gene fragment. The total PCR reaction volume of $50 \mu$ comprised $100 \mathrm{ng}$ genomic DNA, $1 \mu$ l of each primer $\left(10 \mu \mathrm{mol}^{-1} \mathrm{l}^{-1}\right), 22 \mu \mathrm{l}$ sterile water, and $25 \mu 12 \times$ PCR mix with Taq polymerase (Beijing Tsingke Biotech Co., Ltd., Beijing, China). PCR amplification was performed using a BIO-RAD Thermal Cycler (Bio-Rad, Hercules, California USA) with a thermocycling regime of 94 ${ }^{\circ} \mathrm{C}$ for 3 min followed by 34 cycles $94{ }^{\circ} \mathrm{C}$ for $30 \mathrm{~s}, 58{ }^{\circ} \mathrm{C}$ for $30 \mathrm{~s}$, and $72{ }^{\circ} \mathrm{C}$ for $1 \mathrm{~min}$ and a final elongation step of $72^{\circ} \mathrm{C}$ for 5 min. PCR products were purified using a QIAquick PCR Purification Kit (Qiagen, Hilden, Germany) and a TSINGKE DNA Gel Extraction Kit (Beijing Tsingke Biotech Co., Ltd., Beijing, China) and were then cloned using a pMDTM18-T vector (TaKaRa, TaKaRa BioInc., Otsu, Japan). Clones including the target fragment were sequenced bidirectionally using an ABI 3730 Automated Sequencer (PerkinElmer, Waltham, Massachusetts USA).

Phylogenetic analyses. The produced $16 \mathrm{~S}$ rRNA sequences of CHAB 4018 were BLAST-searched using the NCBI online tool, and reference sequences with high similarities were retrieved from GenBank to reconstruct the strain's molecular phylogeny. All downloaded sequences were edited using MAFFT v7.312 software (KATOH et al. 2013) after multiple sequence alignment, and a matrix of 88 sequences with 1164 nucleotide sites was produced. For phylogenetic analysis of the 16S rRNA gene, alignments were analyzed using the standard selection nucleic acid substitution model $(\mathrm{GTR}+\mathrm{I}+\mathrm{G})$ based on the Akaike Information Criterion (AIC) for Bayesian analysis (BI) and maximum likelihood analysis (ML). Selected parameters were individually estimated using MrBayes v3.2.6 (RonQuist et al. 2012) and PhyML 3.0 (GuINDON et al. 2010). The Kimura-2 model was selected with 1,000 bootstrap replicates using MEGA software v7.0 to perform neighbor joining (NJ) analysis (KumAR et al. 2016). ML and Bayesian phylogenetic trees were visualized using FigTree v1.4.3, and all phylogenetic trees were edited using Tree View 1.6.6 software (PAGe 1996). A similarity matrix of the 16S rRNA sequences was established using MEGA v7.0 to calculate $\mathrm{p}$-distance with pairwise deletion of gaps.

Analyses of secondary structures of ITS between $16 \mathrm{~S}$ and 23S rRNA genes. Presence of tRNA gene sequences was tested using the tRNAscan-SE 2.0 web server (LowE \& CHAN 2016). The 16S-23S rRNA ITS secondary structures of the D1-D1' helix of Neochroococcus gongqingensis CHAB 4018 and other 
closed genera were determined using the Mfold 3.2 web server (ZUKER 2003). The 16S-23S rRNA sequences produced in this study were deposited in the GenBank database under the accession numbers MT011390, MT011391 and MT011392.

\section{RESULTS}

Neochroococcus R. Geng et G. Yu gen. nov.

Description: Colonies microscopic, usually small, regular cubic, with 8-16 cells, more or less grouped together; sometimes large colonies composed of sub-colonies; colonies olive-green or red-brown, surrounded by mucilaginous envelopes; mucilage fine, homogeneous and colorless; cells usually spherical or hemispherical after division, with granular content, blue-green, grey-green, olive-green, yellowish, or red-brown; cells arranged three-dimensionally in perpendicular rows and divide regularly in three perpendicular planes in subsequent generations; thylakoids irregularly arranged.

Type species: Neochroococcus gongqingensis R. Geng et G. Yu sp. nov.

Etymology: The name of new genus "Neochroococcus" was chosen because it was more closely related to Chroococcus 'sensu stricto' than to Eucapsis.

Diagnosis: Using light microscopy, this species appears morphologically similar to the genus Eucapsis regarding colonial form and cellular spatial arrangement. However, the phylogenetic tree produced from $16 \mathrm{~S}$ rRNA gene sequences indicated that this species held a unique position in the family Chroococcaceae and was close to the recently established genus Cryptococcum but separated from the Chroococcus 'sensu stricto' clade and Eucapsis. In addition, the 16S rRNA sequence of this strain showed low similarity with those of Eucapsis spp. and of the genus Cryptococcum, and significant differences in the secondary structure of the $16 \mathrm{~S}-23 \mathrm{~S}$ ITS region also supported the establishment of this new cyanobacterial genus.

\section{Neochroococcus gongqingensis R. Geng et G. Yu sp. nov. (Fig. 1)}

Description: Colonies are microscopic, small, more or less regular cubic, typically with 8-16 cells, sometimes grouped together, large colonies composed of subcolonies. Colonies are surrounded with mucilage, but single cells are not. Mucilage fine, homogeneous, colorless, not stratified or diffluent; cells hemispherical to rounded, sometimes oval, with a diameter of 8.44-(10.25)-12.32 $\mu \mathrm{m}$; content granular, blue-green, grey-green, or olive-green in growth phase, and yellowish, yellow or red-brown in decline phase; cells arranged three-dimensionally in perpendicular rows and divided regularly in three perpendicular planes in the subsequent generation, more often forming cube colony morphology of eight cells. Thylakoids are irregularly arranged at the periphery of cells (Fig. 2). Ecology: this species is planktic and inhabits mesotrophic water.

Designated holotype: Dry material of strain CHAB 4018 was stored at the Freshwater Algal Herbarium (HBI), Institute of Hydrobiology, Chinese Academy of Sciences, Wuhan, China, with specimen number as JXGQ201806. Reference strain: The living culture of strain $\mathrm{CHAB}$ 4018 was archived at the Collection of Harmful Algae Biology (CHAB), Institute of Hydrobiology, Chinese Academy of Sciences, Wuhan, Hubei Province, China. Type locality: In a watercourse at the Poyang Lake Model Research Base in the city of Gongqing, Jiangxi province, China. (22th June 2018, site 29 $12^{\prime} 59.44 " \mathrm{~N}$, $\left.115^{\circ} 49^{\prime} 55.86^{\prime \prime} \mathrm{E}\right)$.

Etymology: gongqingensis comes from Latin "gongqing", which refers to the Gongqing city where the strain was collected.

Habitat: Free-living in freshwater channels.

\section{Molecular and phylogenetic analyses}

After calculating $\mathrm{p}$-distance with pairwise deletion of gaps using MEGA software v7.0, a 16S rRNA similarity matrix was produced using 88 sequences downloaded from GenBank. The 16S rRNA sequences of Neochroococcus gongqingensis CHAB 4018 shared 99.65\%-99.91\% similarity among all three clones, and the three clones showed maximum similarity as $93.40 \%$ with the closest coccoid genera (similarities with Gomphosphaeria, Inacoccus, Stanieria, and Chroococcopsis were 93.13\%-93.40\%, 92.96\%-93.31\%, 92.84\%-93.10\%, and 92.75\%-93.02\%, respectively; similarities with Cyanothece, Cryptococcum, Chondrocystis, Aphanothece, Gloeothece, Chroococcus, and Limnococcus were 92.24\%-92.85\%, 88.62\%-92.77\%, $92.16 \%-92.42 \%, 92.14 \%-92.41 \%, 88.69 \%-92.14 \%$, 90.48\%-92.07\%, and 91.79\%-92.06\%, respectively; similarities with Gloeocapsopsis, Synechocystis, Eucapsis, and Merismopedia were $90.89 \%-91.96 \%, 91.73 \%-91.80 \%$, 91.17\%-91.72\%, and 83.19\%-91.70\%, respectively); thus at less than $95 \%$ similarity which is considered the threshold of bacterial intergeneric similarity, this strain probably represents a new cyanobacterial genus (Table 1).

The 16S rRNA NJ, ML, and BI phylogenetic trees (Fig. 3) showed that the three clones of CHAB 4018 clones clustered as a unique clade (cluster A), which was supported by NJ, ML, and BI calculations with high bootstrap values of $99 \%, 100 \%$, and 0.90 respectively; this clade was close to the genera Cryptococcum (cluster C) and Inacoccus (cluster B) but distant from Chroococcus (cluster D) and Eucapsis (cluster E). In this phylogenetic tree, cluster D included Chroococcus minutus, Chroococcus virescens, Chroococcus turgidus, and Chroococcus subviolaceus, and together they formed the Chroococcus 'sensu stricto' clade.

\section{Analyses of ITS secondary structures}

The obtained 16S-23S ITS regions of $N$. gongqingensis CHAB 4018 together with the sequences downloaded 


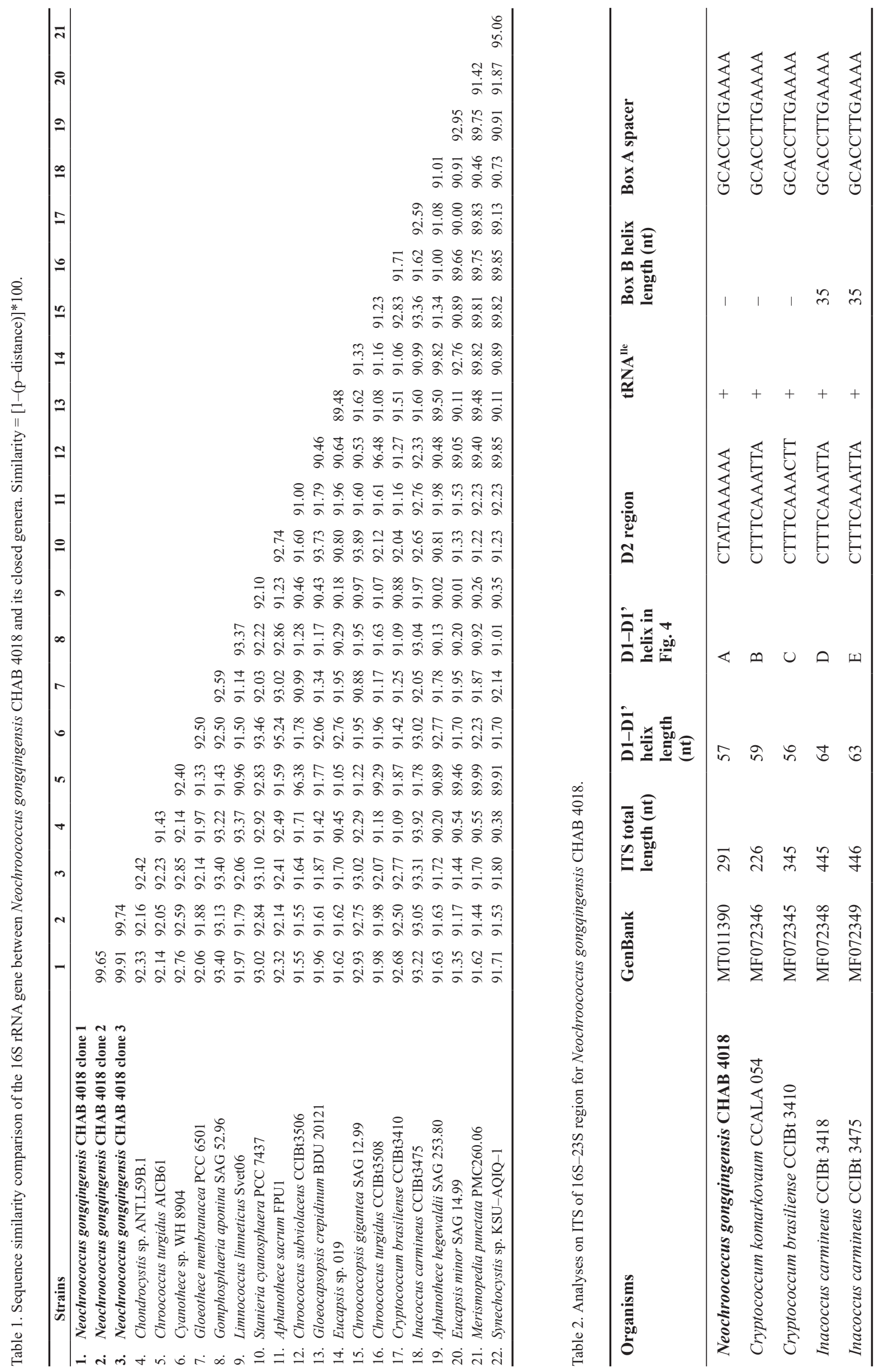


from NCBI were used to reconstruct the ITS secondary structure. The analyses indicated that the ITS of the 16S-23S region of all CHAB 4018 clones contained only one tRNA ${ }^{\text {Ile }}$ at a total length of $291 \mathrm{bp}$ (Table 2). The D1-D1' helix as the most conservative structure differed largely between CHAB 4018 and other taxa used in this study with the D1-D1' helix of CHAB 4018 showing a larger loop below one small loop and one small unidirectional bulge (Fig. 4).

\section{Discussion}

The polyphasic approach considers morphological, molecular phylogenetic, cytomorphological, and ecological characteristics and is the most appropriate method for characterizing cyanobacterial taxa so as to further resolve their taxonomy (CомтE et al. 2007; ScIUTo et al. 2011; Dvoř́́K et al. 2015; KomÁreK 2018). Previous studies repeatedly indicated that coccoid cyanobacteria are particularly heterogeneous and belong to various phylogenetic lineages (KoMÁREK et al. 2011). According to the latest cyanobacterial system proposed by KOMÁREK et al. (2014), coccoid cyanobacteria comprise five orders (Gloeobacterales, Synechococcales, Pleurocapsales, Chroococcidiopsidales and Chroococcales). One considerable novelty of this new system is that the family Chroococcaceae including the genus Chroococcus and the family Merismopediaceae containing the genus Eucapsis belong to Chroococcales and Synechococcales respectively, suggesting substantial phylogenetic distance between these two families.

In the current study, we aimed to extend a polyphasic

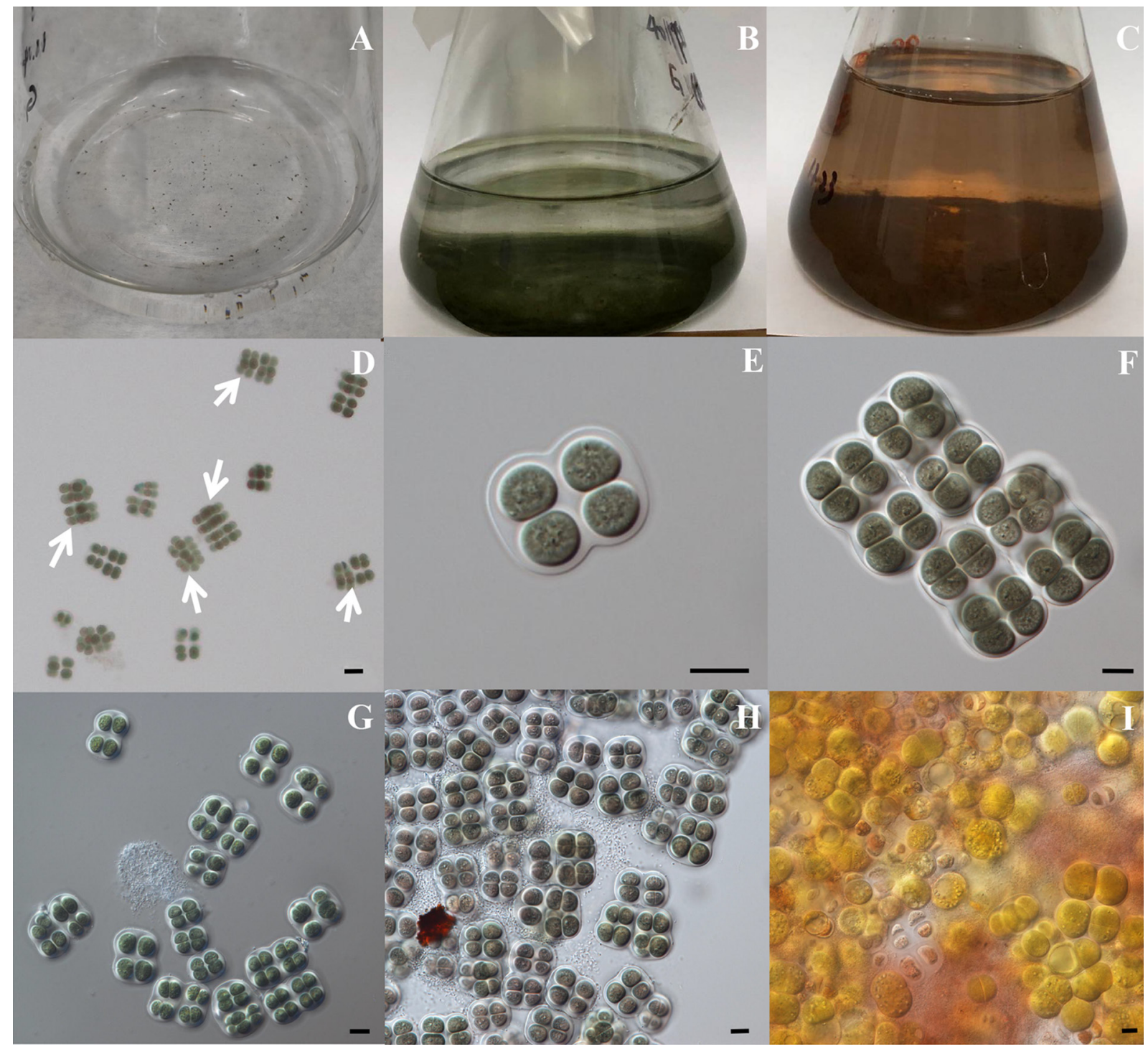

Fig. 1. Light microscopy of Neochroococcus gongqingensis CHAB 4018: (A-C) cells of Neochroococcus gongqingensis CHAB 4018 in the growth, stability and decline phase in liquid MA medium; (D) arrows indicate the cube colony morphology of CHAB 4018; (E) CHAB 4018 cells with a sheath; (F-G) CHAB 4018 colonies under different growth conditions; (H) Cells of CHAB 4018 began to turn red; (I) CHAB 4018 colonies of 7-month-old. Scale bars $20 \mu \mathrm{m}$ (D), $10 \mu \mathrm{m}$ (E-I). 
investigation to coccoid cyanobacteria by using our newly isolated strain from a subtropical freshwater channel in the city of Gongqing. Using light microscopy, strain CHAB 4018 showed cubic colonies within an envelope containing up to eight cells, which is a relatively typical colonial form of the genus Eucapsis. The cell size of this strain was within the range of the type species E. alpina; however, each cubic colony of strain $\mathrm{CHAB}$ 4018 comprised fewer cells than those of E. alpina, and strain CHAB 4018 is planktic in mesotrophic water, whereas E. alpina occurs predominantly in littoral areas of mesotrophic swamps (KomáreK et al. 2016). The novel strain was also similar to Chroococcus prescottii regarding cellular morphology and cubic colonial form; however, the latter typically produces smaller cells (5-8 $\mu \mathrm{m}$ in diameter) and sarcinoid clusters. Further morphological observations revealed a change in cell color from green to red in all cultivations of this new strain (Fig. $2 \mathrm{H}$ ), which differs from the species Inacoccus CCIBt 3475 which produces red-colored sheaths (GAmA et al. 2019) and from Eucapsis spp. and Chroococcus spp. Comparison of the 16S rRNA gene sequences showed maximum similarity of $93.40 \%$ of strain CHAB 4018 with previously identified cyanobacterial taxa, which is below the threshold value for bacterial genus and species delimitation as proposed by WAYNE et al. (1987), STACKEBRANDT \& GOEBEL (1994) and STACKEBRANDT \& EBERS (2006). Therefore, strain CHAB 4018 most likely represents a novel cyanobacterial genus. The
ITS secondary structure including differences in the D1-D1' helix also supported that this taxon belongs to a new genus (Fig. 4). Phylogenetic tree based on the 16S rRNA gene sequences further showed that the strain CHAB 4018 was separated from the Chroococcus 'sensu stricto' clade (cluster D) and the recently defined Eucapsis mentioned above. Strain CHAB 4018 was further shown to be more closely related with Chroococcus 'sensu stricto' than with Eucapsis. Recent taxonomic revisions of Chroococcus-like cyanobacteria led to substantial modifications and new insight into the taxonomy of the genus Chroococcus, and phylogenetic results produced from Chroococcus strains indicated that some morphological features used for discrimination of Chroococcus species depend on environmental factors (KOMÁRKOvá et al. 2010). Following polyphasic taxonomic investigations of Chroococcus, KomáRKovÁ et al. (2010) and KovéčIK et al (2011) defined one particular clade of Chroococcus strains as the real clade for the genus (Chroococcus 'sensu stricto'). Gama et al. (2019) examined Chroococcus-like strains from the Brazilian Atlantic Forest, and their results led to the establishment of two new genera Inacoccus and Cryptococcus which are related to Chroococcus, and they proposed the large phylogenetic clade Chroococcus 'sensu lato' to include the clades Chroococcus 'sensu stricto', Inacoccus, Cryptococcus, and Limnococcus (Fig. 1, Gama et al. 2019). The genus Limnococcus was described as an independent genus after it was transferred from Chroococcus limneticus by

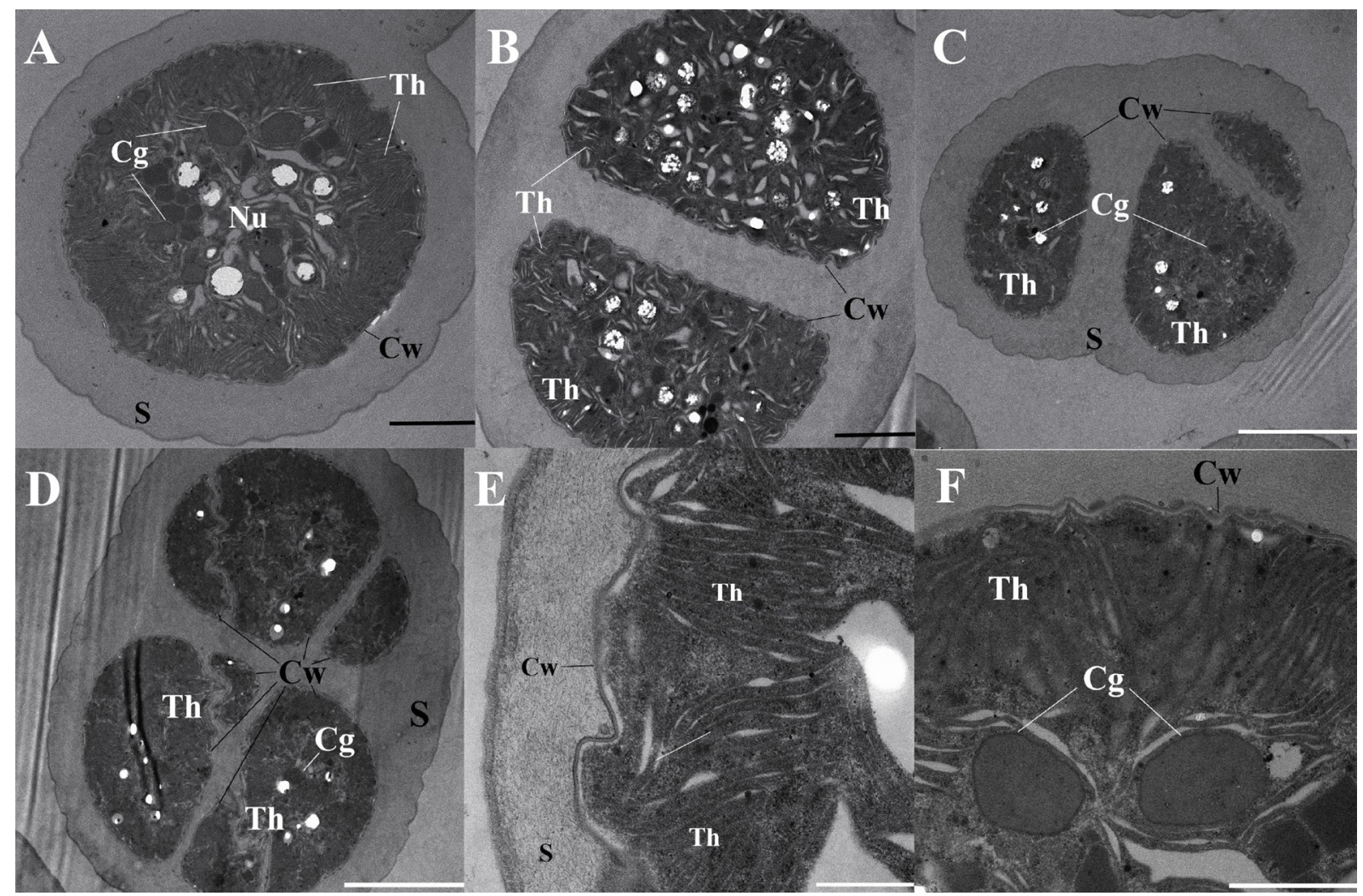

Fig. 2. Ultrastructure of Neochroococcus gongqingensis CHAB 4018: (Cw) cell wall; (Cg) cyanophycin granule; (Th) thylakoids; (Nu) nucleoplasm; (S) sheath. Scale bars $2 \mu \mathrm{m}$ (A-B), $5 \mu \mathrm{m}$ (C-D), $0.5 \mu \mathrm{m}$ (E), $1 \mu \mathrm{m}$ (F). 


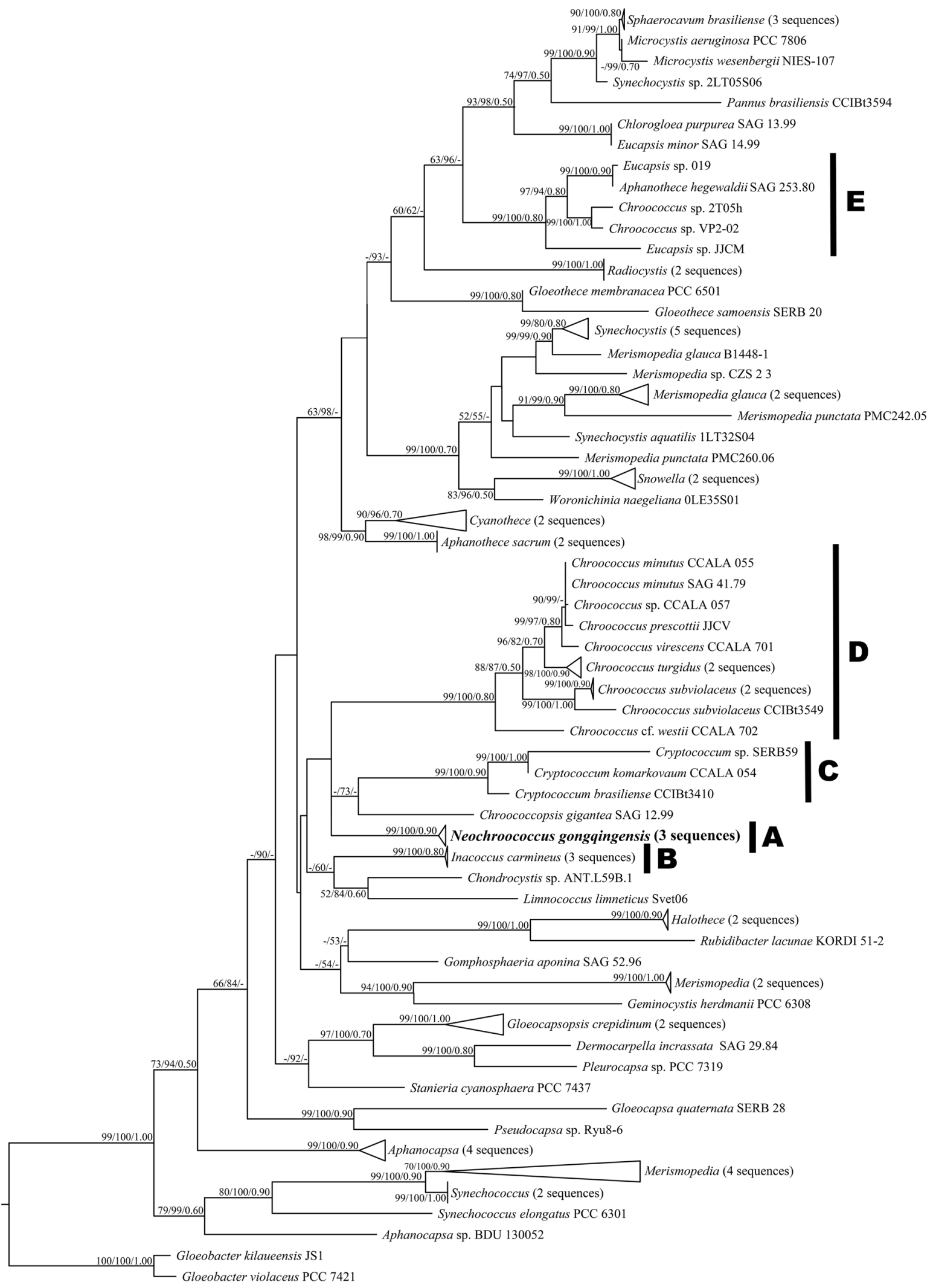

Fig. 3. Phylogenetic tree of 16S rRNA gene sequences (1164bp) derived from maximum-likelihood (ML) analysis. Bootstrap values of NJ / ML / BI methods greater than $50 \%$ are showed on the ML tree. The novel coccoid strain of this study is indicated in bold. Bar, 0.06 . 
KomÁRKová et al. (2010), and its distant generic position was verified. Limnococcus was further placed in the family Merismopediaceae rather than Chroococcaceae in the latest system of cyanobacterial taxonomy by KomÁREK et al. (2014); however, phylogenetic support for this placement is lacking so far. Phylogenetic trees produced by KomÁRKOvá et al. (2010) and KomÁREK et al. (2016) did not clearly support Limnococcus to belong to Merismopediaceae. In contrast, the phylogenetic results of the present study suggested that Eucapsis-like strain CHAB 4018 is part of the large Chroococcus 'sensu lato' clade and is more closely related to Limnococcus and Chroococcus 'sensu stricto' than to the Eucapsis clade. Consistent with GAma et al. (2019), our results indicated that Limnococcus was more closely related to Chroococcus than to Merismopedia and Eucapsis, which challenges the current family placement of Limnococcus. Phylogenetic analyses also showed that Eucapsis minor SAG 14.99 did not group with the other five strains of the defined Eucapsis clade (Fig. 3 cluster E). Thus, the diversity of Eucapsis-like cyanobacteria, even with regard to only a limited number of strains, was higher than expected in the present study.

In conclusion, polyphasic taxonomic assessment of the novel strain Neochroococcus gongqingensis $\mathrm{CHAB}$ 4018 showed morphological differences, 16S rRNA gene dissimilarity, and differences in the secondary structure of ITS, and its phylogenic relationship among the examined coccoid cyanobacteria supported the establishment of Neochroococcus gen. nov. and Neochroococcus gongqingensis sp. nov. Eucapsis-like cyanobacteria showed higher diversity than expected. A relatively large phylogenetic tree comprising more strains suggested phylogenetic intermixture of Chroococcus-like and Eucapsis-like cyanobacteria which further elucidates the phylogeny and taxonomy of coccoid cyanobacteria.

\section{ACKNOWLEDGEMENTS}

This study was funded by NWSTP (No. 2017ZX07203-003), NSFC (No. 51779247) and Research Project of Jiangxi Water Resource Agency (201821ZDKT11). The first author thanks Zhenfei Xing (IHB, CAS) and Yuan Xiao (IHB, CAS) for technical assistance with TEM images.

\section{REFERENCES}

Clements, F.E. \& H.L. Shantz. (1909): A new genus of blue-green algae. - Minnesota Bot. Stud. 4: 133-135.

Comte, K.; Holland, D. P. \& Walsby, A.E. (2007): Changes in cell turgor pressure related to uptake of solutes by Microcystis sp. strain 8401. - FEMS microbiology ecology 61: 399-405.

DvoŘÁK, P.; PoulíčKovÁ, A.; HaŠler, P.; Belli, M.; CASAMATTA, D. A. \& PAPINI, A. (2015): Species concepts and speciation factors in cyanobacteria, with connection to the problems of diversity and classification. - Biodiversity and Conservation 24: 739-757.

Edwards, U.; Rogall, T.; BlÖCKer, H.; EMde, M. \& BÖTtGER, E.C. (1989): Isolation and direct complete nucleotide determination of entire genes. Characterization of a gene coding for $16 \mathrm{~S}$ ribosomal RNA. - Nucleic acids research 17: 7843-7853.

ELENKIN, A.A. (1933): Osistematicheskom podrazdelenii poryadka Chroococcales Geitler (1925). - Trudy Bot. Inst. Akad. Nauk SSSR, Ser. 2: 17-21.

Gama, W.A.; Rigonato, J.; Fiore, M. F. \& Sant'Anna, C. L. (2019): New insights into Chroococcus (Cyanobacteria) and two related genera: Cryptococcum gen. nov. and Inacoccus gen. nov. - European Journal of Phycology
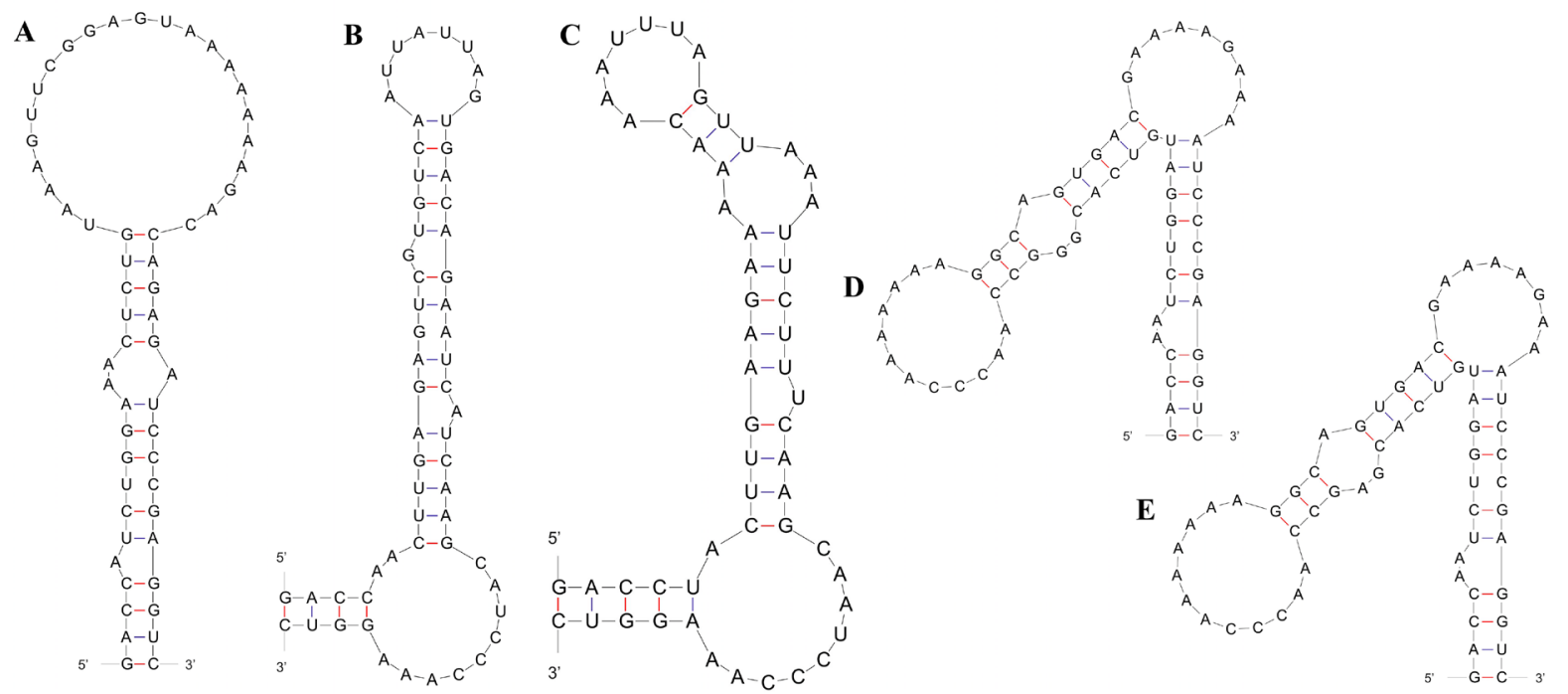

Fig. 4. D1-D1' helix in Neochroococcus gongqingensis, Cryptococcum strains and Inacoccus strains: (A) Neochroococcus gongqingensis CHAB 4018; (B) Cryptococcum komarkovaum CCALA 054; (C) Cryptococcum brasiliense CCIBt 3410; (D) Inacoccus carmineus CCIBt 3418; (E) Inacoccus carmineus CCIBt 3475. 
61: 1-11.

Gkelis, S.; Rajaniemi, P.; Vardaka, E.; Moustaka-Gouni, M.; LANARAS, T. \& Sivonen, K. (2005): Limnothrix redekei (Van Goor) Meffert (Cyanobacteria) strains from Lake Kastoria, Greece form a separate phylogenetic group. - Microbial Ecology 49: 176-182.

Guindon, S.; Dufayard, J.F.; Lefort, V.; Anisimova, M.; HordiJK, W. \& GASCuEl, O. (2010): "New Algorithms and Methods to Estimate Maximum-Likelihood Phylogenies: Assessing the Performance of PhyML 3.0.". - Systematic Biology 59: 307-321.

Katoh, K. \& Standley, D.M. (2013): MAFFT multiple sequence alignment software version 7: improvements in performance and usability. - Molecular biology and evolution 30: 772-780.

KomÁReK, J. \& ANAGnostidis, K. (1998). Cyanoprokaryota-1. Teil/1st part. Chroococcales. - In: GARTNER, E.H.; Heynig, H. \& Mollenhauer, D. (eds): Süsswasserflora von Mitteleuropa. - pp. 1-50, Gustav Fischer, Jena, Germany.

KomáreK, J.; Kaštovský, J.; Mareš, J. \& Johansen, J.R. (2014): Taxonomic classification of cyanoprokaryotes (cyanobacterial genera) 2014, using a polyphasic approach. - Preslia 86: 295-335.

KomÁReK, J. (2016): Review of the cyanobacterial genera implying planktic species after recent taxonomic revisions according to polyphasic methods: state as of 2014. - Hydrobiologia 764: 259-270.

KomáreK, J.; HindaK, F. \& Jezberova, J. (2016): Review of the cyanobacterial genus Eucapsis. - Nova Hedwigia 103: 441-456.

KomÁreK, J. (2018): Several problems of the polyphasic approach in the modern cyanobacterial system. Hydrobiologia 811: 7-17.

KomÁrková J.; JezberovÁ J.; KOMÁreK O. \& ZAPOMĚLová E. (2010): Variability of Chroococcus morphospecies (Cyanobacteria) in phylogenic relationships. Hydrobiolgia 639: 69-83.

KováčIK, L.; Jezberová, J.; KomÁrková, J.; KopeckÝ, J. \& KomÁreK, J. (2011): Ecological characteristics and polyphasic taxonomic classification of stable pigment-types of the genus Chroococcus (Cyanobacteria). - Preslia 83: 145-166.

Kumar, S.; Stecher, G. \& TAmura, K. (2016): MEGA7: Molecular Evolutionary Genetics Analysis version 7.0 for bigger datasets. - Molecular biology and evolution 33: $1870-1874$.

Lowe, T.M. \& ChAN, P.P. (2016): tRNAscan-SE On-line: integrating search and context for analysis of transfer
RNA genes. - Nucleic acids research 44: W54-W57. Neilan, B.A.; Jacobs, D. \& Goodman, A.E. (1995): GenetiC DIVERSITY AND PHYLOGENY of toxic cyanobacteria determined by DNA polymorphisms within the phycocyanin locus. - Applied and Environmental Microbiology 61: 3875-3883.

Page, R.D.M. (1996): TreeView: An application to display phylogenetic trees on personal computers. - Computer Applications in the Biosciences 12: 357-358.

Ronquist, F.; Teslenko, M.; Van Der Mark, P.; Ayres, D. L.; Darling, A.; HöHnA, S. \& Huelsendeck, J.P. (2012): MrBayes 3.2: efficient Bayesian phylogenetic inference and model choice across a large model space. Systematic biology 61: 539-542.

Sciuto, K.; Rascio, N.; Andreoli, C. \& Moro, I. (2011): Polyphasic characterization of ITD-01, a cyanobacterium isolated from the Ischia Thermal District (Naples, Italy). - Fottea 11: 31-9.

SPURR, A.R. (1969): A low-viscosity epoxy resin embedding medium for electron microscopy. - Journal of ultrastructure research 26: 31- 43.

Stackebrandt, E. \& Goebel, B.M. (1994): Taxonomic note: a placefor DNA-DNA reassociation and 16S rRNA sequence analysisin the present species definition in bacteriology. - International Journal of Systematic Bacteriology 44: 846-849.

STACKEBRANDT, E. \& EBERs, J. (2006): Taxonomic parameters revisited: tarnished gold standards. - Microbiol. Today 33: $152-155$.

Watanabe, M. M. \& Hiroki, M. (1997): NIES-Collection List of Strains: Algae and Protozoa. - p. 140, National Institute for Environmental Studies, Environment Agency, Tsukuba, Japan.

WAYNE, L.G.; BrenNer, D.J.; Colwell, R.R.; Grimont, P.A.D.; KANDLER, O.; KRICHEVSKY, M.I. \& StaRR, M.P. (1987): Report of the ad hoc committee on reconciliation of approaches to bacterial systematics. - International Journal of Systematic and Evolutionary Microbiology 37: 463-464.

ZuKER, M. (2003): Mfold web server for nucleic acid folding and hybridization prediction. - Nucleic acids research 31: 3406-3415.

(C) Czech Phycological Society (2021)

Received May 27, 2020

Accepted November 3, 2020 